\title{
Különböző színhőmérsékletü fényforrások rovarvonzó hatásának természetvédelmi szempontú vizsgálata
}

\author{
Gyarmathy István ${ }^{1 *}$, Korompai Tamás ${ }^{2}$, Mester Béla ${ }^{1}$ és \\ Novák Richárd ${ }^{2}$ \\ ${ }^{1}$ Hortobágyi Nemzeti Park Igazgatóság, 4024 Debrecen, Sumen u. 2. \\ ${ }^{2}$ Bükki Nemzeti Park Igazgatóság, 3304 Eger, Sánc u. 6. \\ *E-mail: gyarmathyistvan@hnp.hu
}

\begin{abstract}
Összefoglaló: Kutatásunk elsődleges célja az eltérő színhőmérsékletü, közvilágításban is használt lámpák ökológiai hatásának elemzése volt. A fénycsapdák által vonzott ízeltlábúak mennyiségi adatait egy automatikus mintavevő (Zoolog) rögzítette, a hőmérséklet- és páratartalom-adatokkal egyidejüleg. A nagy mennyiségü adat statisztikai elemzésével lehetőség nyílt a különböző típusú fényforrások által élőhelyükröl elvonzott ízeltlábúak biomassza-mennyiségének hosszabb távú nyomon követésére, ezáltal a különböző színhőmérsékletű lámpák attraktivitásának elemzésére, illetve a napi és hosszabb távú aktivitásváltozások vizsgálatára is. A befogott biomassza száraztömegének mérése kiegészítette a fenti vizsgálatot. Mindezek lehetővé teszik a természetvédelmi kezelést, illetve a világítás védett területen történő szabályozását elősegítő következtetések levonását.
\end{abstract}

Kulcsszavak: fényszennyezés, távérzékelés, fénycsapda, természetvédelmi kezelés

\section{Bevezetés}

A fényérzékenység alapvető tulajdonság sokféle állat, különösen az ízeltlábúak esetében. A rovarok a fény széles spektrumára érzékenyek, az ember számára láthatatlan ultraibolyától (UV) a vörösig. Orientációjuk, napi aktivitásuk és éves ritmusuk nagymértékben függ a fényektől és a természetes fénymintáktól. A fényérzékenység táplálkozásukban és a szaporodásukban is fontos szerepet játszik. A rovarok a megvilágítás forrása felé haladnak, de a fény eltérítheti vagy taszíthatja őket (pozitív vagy negatív fototaxis), növelheti vagy csökkentheti aktivitásukat (Bertholf 1940). A növekvő kültéri világítás napjainkban jelentös természetvédelmi problémát jelent. A közvilágításban használt lámpatestek gyakorlatilag fénycsapdákként müködnek. Sötét területeken egy fényforrás akár tízezres nagyságrendủ rovaregyedet is képes bevonzani egy éjszaka során. A mesterséges fények által élőhelyükről eltávolított - és többnyire elpusztított - rovarok mennyisége 
óriási: egy Egyesült Államokban végzett kutatás során egyetlen fénycsapda 36,8 $\mathrm{kg}$ (kb. 85 millió egyed) iszapszúnyogot (Limonia sp.) fogott el egy éjszaka alatt (Rich és Longcore 2006).

Egy magyar nagyvárosban, megvilágított falfelületek mentén végzett gyüjtés során az 50 alkalommal végzett napi kétórás gyüjtőprogram alatt 148 futóbogárfaj (Carabidae) 17400 példányát azonosították. Ez az összes befogott rovar 20\%-a volt. Külön érdekesség, hogy ez a pár tíz négyzetméteres megvilágított falfelület 25-30 km-es távolságban lévő szikes élőhelyekröl is vonzott fajokat - vélhetöen az élőhelyükről elkóborolt egyedek kerültek a fény hatósugarába (Ködöböcz 2018). A jelentős fényszennyezést okozó világítótestek vagy megvilágított felületek rövid időn belül olyan mértékben vonzhatják magukhoz a rovarokat, hogy a sötétebb élőhelyeken nem marad elegendő rovar táplálékként a ragadozók számára. Ez a folyamat - a fényszennyezés fragmentációs hatásával együtt - viszonylag gyorsan és nagy területen a fajkészlet (és így az ökoszisztéma egészének) jelentős átalakulását eredményezheti (Davies et al. 2012). A rovarok fajszáma és egyedszáma Európában az utóbbi időben jelentős mértékben lecsökkent. Feltételezhetjük, hogy ezt - más okok mellett (peszticidhasználat, élőhelyvesztés, stb.) - részben a fényszennyezés okozhatja. Mindezek túlmutatnak az egyes fajokra kifejtett hatásokon, és egyre több a bizonyíték arra, hogy a világszerte növekvő megvilágítás negatív hatással van egész ökoszisztémákra is. Ezért fontos meghatározni azokat a fényforrásokat és megvilágítási módokat, amelyek a legkevésbé károsítják a természeti környezetet, beleértve a táplálkozási láncban kulcsszerepet játszó rovarvilágot.

A megvilágításra adott különböző válaszok összefüggenek a fény intenzitásával, spektrumával és polarizációjával. Ha meg akarjuk találni ennek a vonzerőnek az okait, meg kell vizsgálnunk a fiziológiai gyökereket, valamint a rovarok viselkedését. A vonzerő a rövidebb hullámhossznak és a magasabb frekvenciának köszönhetö, míg a nagyobb hullámhosszú vörös fény a rovarok számára nehezebben észlelhető. A rovaroknak az összetett szemük mellett három pontszemük (ocelli) van, melyek feladata a fény, és nem a mozgás azonosítása. Úgy tünik, a pontszemek a rövidebb hullámhosszokat könnyebben felismerik.

Sok rovar szürkületben táplálkozik, amikor a kék fény uralja az ég sugárzási spektrumát. A napnyugta és a csillagászati szürkület közötti 1-2 órán át a kék felé eltolódott fények állandó polarizációs mintázatot, ezáltal orientációs lehetőséget biztosítanak a rovarok számára (Cronin et al. 2006). Csillagfényben a besugárzási spektrumok „,vöröseltolódnak”, és erősen befolyásolja őket a Hold jelenléte vagy hiánya. Ez megmagyarázza, hogy a különböző fényforrások vonzó hatása miért függ a spektrális összetételtől. A kék vagy hideg fehér fényt kibocsátó fémhalogén lámpáknak vagy LED-eknek 6-10-szer nagyobb vonzó hatása van a lepkék szá- 
mára, mint a hosszabb hullámhosszú (meleg fehér vagy sárga fényü) nátriumlámpáknak. Tehát a lepkék számára a hideg fénnyel rendelkező LED akár 10-szer fényesebbnek tủnik, mint az azonos intenzitású sárga nátriumlámpák (Huemer et al. 2010).

A fenti ismeretek alapján a közvilágításban széles körben használt különféle típusú fényforrások rovarvonzó hatását vizsgáltuk meg. Feltételeztük, hogy a színhőmérséklet és a lámpák fényének spektrális összetétele fontosabb, mint a lámpák fényereje. Ennek igazolására különféle színhőmérsékletü, spektrális összetételü és fényerősségü fényforrásokat alkalmazó csapdákat használó kutatóprogramot indítottunk. A befogott rovarok számlálásához újszerü távérzékelési módszert is alkalmaztunk: a ZooLog mintavételi rendszert, az Edapholog szondák továbbfejlesztett változatát (Dombos et al. 2017).

\section{Anyag és módszer}

Négy Jermy-típusú fénycsapdát használtunk (1., 2. ábra), amelyek 4000 és 2700 Kelvin színhőmérsékletủ és némileg eltérő fényerejű lámpákkal voltak felszerelve: (i) 4000 Kelvin színhőmérsékletü (hideg fehér), 3100 lumen fényerejü higanygőzlámpa (MVL: mercury vapour lamp). Régi utcai világítási rendszerekben és fénycsapdákban is használták. (ii) A kísérleti időszak elején, 2020. május 8-ig egy UV rovarcsapda fénycsövet használtunk (BL368 jelü) vélelmezve, hogy ez lesz a legattraktívabb a rovarok számára. (iii) Május 8-a után az előző helyett a végleges fényforrás két db 4000 Kelvines (hideg fehér), összesen 3040 lumenes kompakt

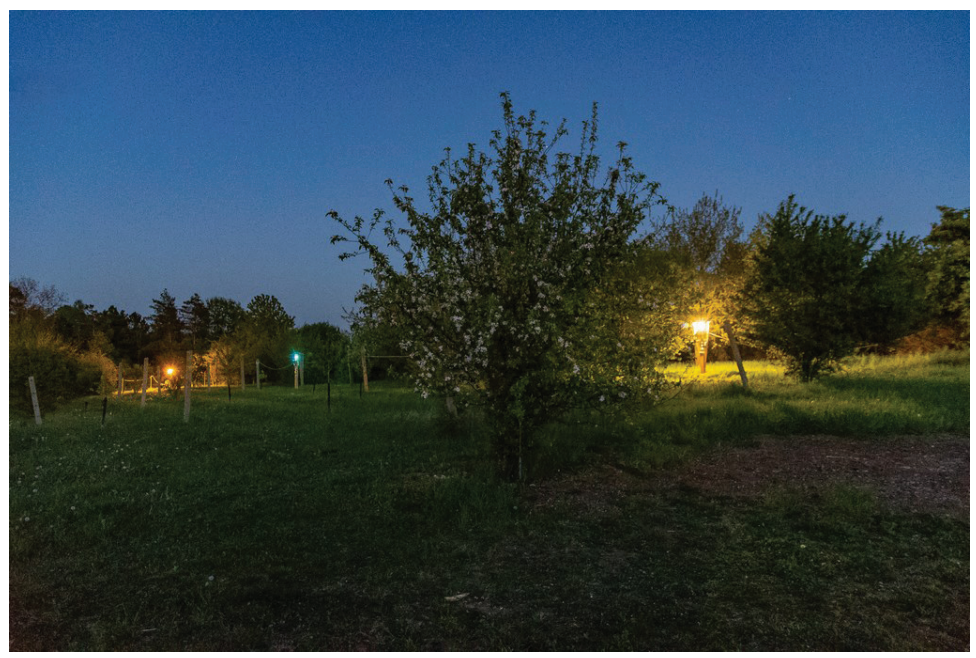

1. ábra. Jermy-csapdák, különféle típusú lámpákkal. 


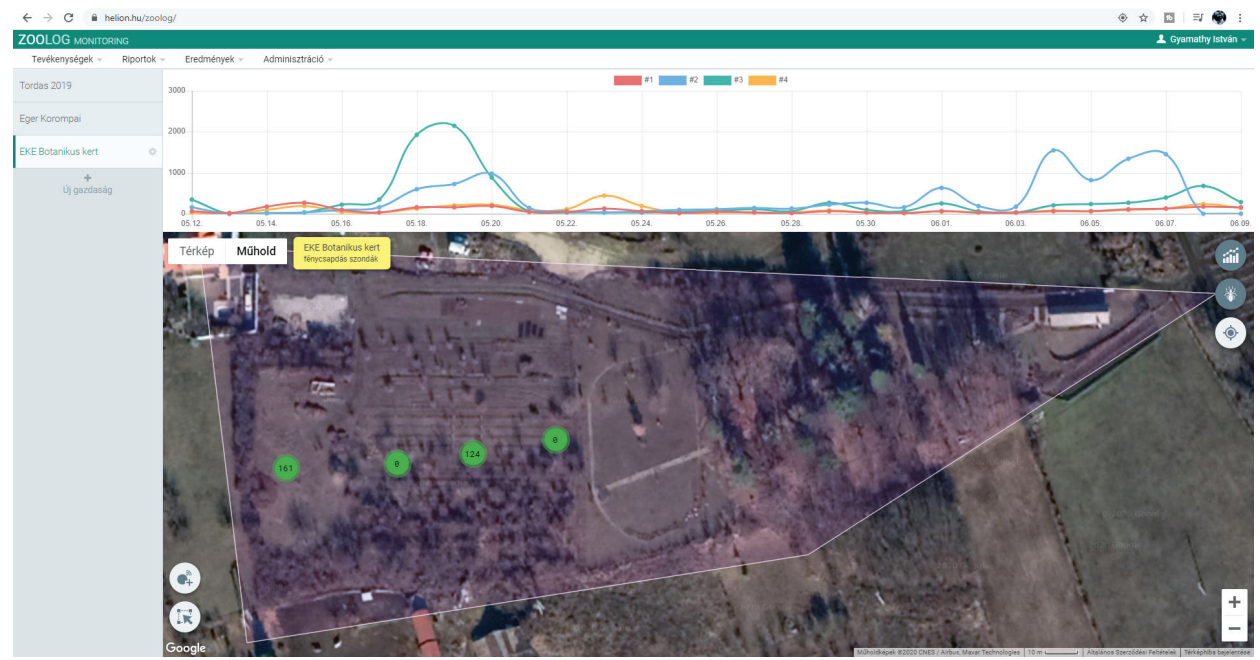

2. ábra. A Zoolog adatgyűjtő eredményei online nyomon követhetőek (a képen a csapdák elhelyezkedése is látható a Botanikus Kertben) (http1).

fénycső (CFL: compact fluorescent lamp) volt. (Azért kellett két darabot használni, hogy a szokványos közvilágítási fényáramot reprodukálhassuk.) Jelenleg ez a legelterjedtebb lámpatípus az utcai világításban. (iv) 4000 Kelvines (hideg fehér), 2450 lumenes LED lámpa; ezt használják jelenleg leggyakrabban az utcai világítások korszerüsítésénél. (v) 2700 Kelvines (sárga színü), 2450 lumenes LED lámpa; a jelenlegi vélemények szerint ez javasolandó a természetvédelmi elöírásokban (3. ábra). (Megjegyezzük, hogy a csapdákban használt fényforrások

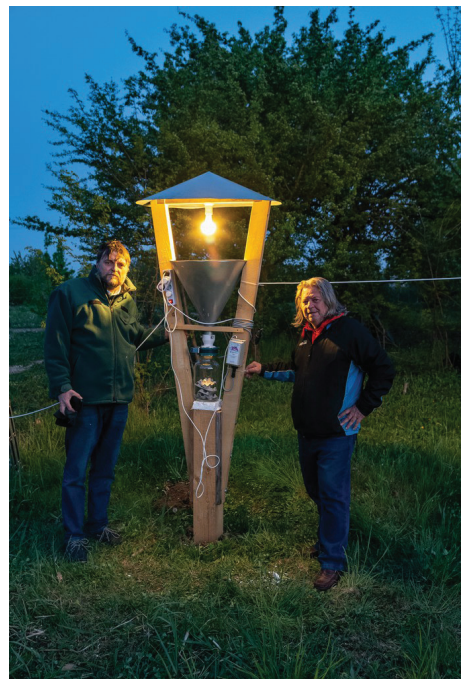

3. ábra. Jermy-csapda sárga LED-del és Zoolog szondával felszerelve. 
esetében az MVL kivételével csak a fényerő, a színhőmérséklet és a müködési elv egyezett a közvilágításban használatos fényforrásokkal.)

Mivel - miként később bemutatott vizsgálataink ezt alátámasztják - a 4000 Kelvin színhőmérsékletủ lámpák attraktivitása jelentősen eltér (az azonos színhőmérsékletü CFL lámpa attraktivitása meghaladja a szintén 4000 Kelvines LEDét), szükségesnek tartottuk a lámpák fényének spektrális vizsgálatát. Feltételeztük, hogy a CFL spektrumának több kék komponenst kell tartalmaznia, mint a LEDnek. A szakirodalmi adatok ezt alátámasztják. A mérések szerint (Ferreirade et al. 2019, Benxuan et al. 2020) a CFL lámpák spektrális eloszlása vonatkozásában a rövid hullámhosszú kék radiancia mennyisége jelentősen meghaladja az azonos színhőmérsékletủ LED lámpák által kibocsátott rövid hullámhosszú radianciát. Sőt, a CFL fényforrás a rovarok számára különösen vonzó UV spektrumot is tartalmaz. A Kolláth Zoltán (Eszterházy Károly Egyetem) által 4000 Kelvines CFL és LED-es fényforrásról készített (még nem publikált) spektrum is alátámasztja ezt.

A Jermy-típusú fénycsapdák alá automatikus számláló érzékelőket telepítettünk (4. ábra), amelyek mobilinternet-kapcsolaton keresztül a következő adatokat szolgáltatják egy központi szerverhez (http1): beeső egyedek száma, a beesés idöpontja, az aktuális hőmérséklet és páratartalom (Dombos et al. 2018). (Emellett a csapda alkalmas egy a testmérettel korreláló érték megadására is, mi ezt technikai okok miatt nem használtuk.)

A monitoring program kalibrációval kezdődött. A rovarok egyedszámát manuálisan számláltuk és hasonlítottuk össze az érzékelők eredményeivel. Az egyes napok gyüjtési eredményeit elkülönítve tároltuk, és néhány hét múlva laboratóriumi mérlegen lemértük a minták száraztömegét. Gépi tanulás segítségével kalibráltuk a szondákat. A csapdákat az egri Eszterházy Károly Egyetem botanikus kertjében

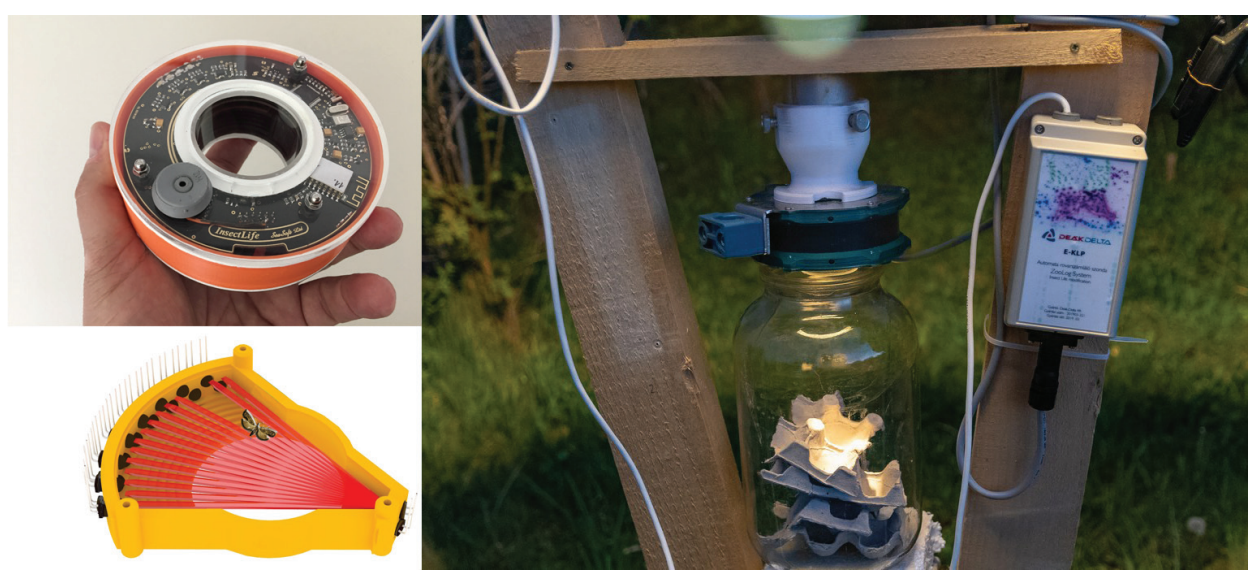

4. ábra. Zoolog érzékelő gyürü és adatgyüjtő, és rögzítése a Jermy-csapdához (fotó: http1). 
helyeztük el, egymástól jól elkülönítve, egy vonalban, közöttük 20, illetve 30 méteres távolsággal (2. ábra). A csapdák 5-10 méteres körzetében a mikroélöhelyek tekintetében inhomogenitást feltételeztünk, ezért az adott csapdák lámpáit szabályos ütemben estéről-estére cserélgettük. Ez a feltételezés a fajösszetétel és a fogási naplók összevetése után nem nyert bizonyítást. A kalibrálást 2019 végén kezdtük, a tényleges adatgyüjtést 2020 áprilisában indítottuk el, és 2020. november végéig folytattuk.

Az általunk alkalmazott megfigyelőrendszer IR (infravörös) érzékelő gyürüt használ a befogott rovarok detektálására (Balla et al. 2020). A detektálás elve lényegében egy fotocellás kapu, amely a közeli infravörös tartományban müködik a környezeti fény zavaró hatásának csökkentése érdekében. Infravörös fényforrásként egy TSAL6200 típusú LED diódát használunk, amelynek karakterisztikus hullámhossza $940 \mathrm{~nm}$ volt. A pontosságot egy 3D-s tervezési programban készített munkadarab biztosítja. A 3D nyomtatás lehetővé tette a nem kívánt fények kizárását és a szóródás elkerülését, ezáltal csökkentve az eszköz környezeti fényzajra való érzékenységét. A szonda GSM/GPRS modem használatával továbbítja az összegyüjtött adatokat egy központi szerver adatbázisába.

Az adatokat óránkénti összesítésben töltöttük le 2020. április 25. és november 25. között, csak a naplemente és napfelkelte közötti adatokat használva, amikor a gyüjtőedényekkel ellátott Jermy-csapdák világítása üzemelt. Az így létrejött adatbázisból csak azokat az adatsorokat használtuk fel, amelyek esetében csapdanaponként legalább nyolc órányi beérkező adat állt rendelkezésre (az expozíciós csapdaidő az éjszaka hosszának változása miatt 8,5 és 14 óra között volt), illetve amely napokon gyüjtöüveg volt a csapda alatt és a begyüjtött minta feldolgozásra került (ennek adatait egy külön cikkben tesszük közzé). Az adatokat ismétléses mintavétel szerint rendeztük, ahol a négy csapdalokáción belül több gyüjtési dátum (csapdanap) található, melyekhez külön-külön a mért száraztömeg és a fogások Zoolog által közölt egyedszám-értékei összegezve lettek, a páratartalom és hőmérséklet adatrekordok pedig átlagolva. A páratartalom százalékos értékeit transzformáltuk (arcus sinus). R statisztikai környezetben (R 3.6.3, R Development Core Team 2020), általánosított lineáris kevert hatású modellekkel (GLMM) vizsgáltuk négy független változó (fényforrás típusa, expozíciós idő, átlagos hőmérséklet és átlagos páratartalom) hatását két függő változóra (fogott rovarok egyedszáma és száraztömeg), ahol random faktor volt a csapdanap és a csapdalokáció. Elöször a teljes GLMM-eket illesztettük az nlme csomag lme funkciójának segítségével, majd a variancia analízis (ANOVA funkció) után, a nem szignifikáns független változók eltávolításával jutottunk el a minimum adekvát GLMM-ekhez. Szignifikáns hatású faktorok esetében az lsmeans funkcióval számoltuk ki a csoportok igazított átlagait, illetve Tukey HSD teszttel vetettük össze a csoportokat. A korrelációkat ggplotRegression funkcióval vizsgáltuk. 


\section{Eredmények}

A fogott rovarok egyedszámát szignifikánsan befolyásolta az alkalmazott fényforrás típusa $\left(\mathrm{Chi}^{2}=30,7, \mathrm{p}<0.001\right)$, valamint az átlagos hőmérséklet $\left(\mathrm{Chi}^{2}=28,2\right.$, $\mathrm{p}<0.001)$. Az egyedszám szignifikánsan nagyobb volt az MVL esetében mind a 4000, mind pedig a 2700 Kelvines LED fényforrásokhoz képest (5.a ábra, 1. táblázat). A fogott rovarok egyedszáma szignifikánsan nőtt az átlagos hőmérséklettel (6. ábra).

A begyüjtött minták száraztömegét szignifikánsan befolyásolta az alkalmazott fényforrás típusa $\left(\mathrm{Chi}^{2}=101,4, \mathrm{p}<0.001\right)$. A száraztömeg szignifikánsan nagyobb volt az MVL esetében a CFL fényforráshoz képest (5.b ábra, 1. táblázat), azonban az UV lámpa egyik előző fényforrástól sem különült el szignifikánsan (5.b ábra, 1. táblázat). Mind a 4000, mind pedig a 2700 Kelvines LED fényforrás esetében szignifikánsan kisebb volt a száraztömeg a többi fényforráshoz képest (5.b ábra, 1. táblázat). Az egyedszám szignifikánsan nőtt a száraztömeggel (7. ábra). Egy egy éjszaka befogott rovarmennyiséget a 8 . ábra mutat be.
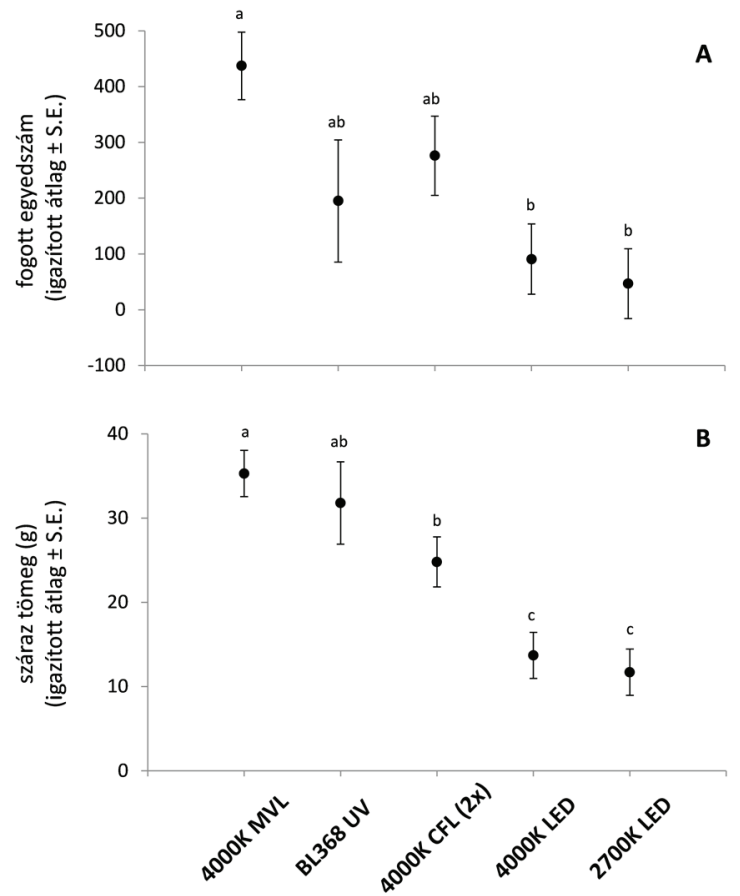

5. ábra. Fogott rovarok egyedszámának (a) és száraztömegének (b) eltérése a különböző fényforrások között. A hibasávok feletti betük az elkülönülés mértékét jelölik (Tukey HSD, p < 0,05). 


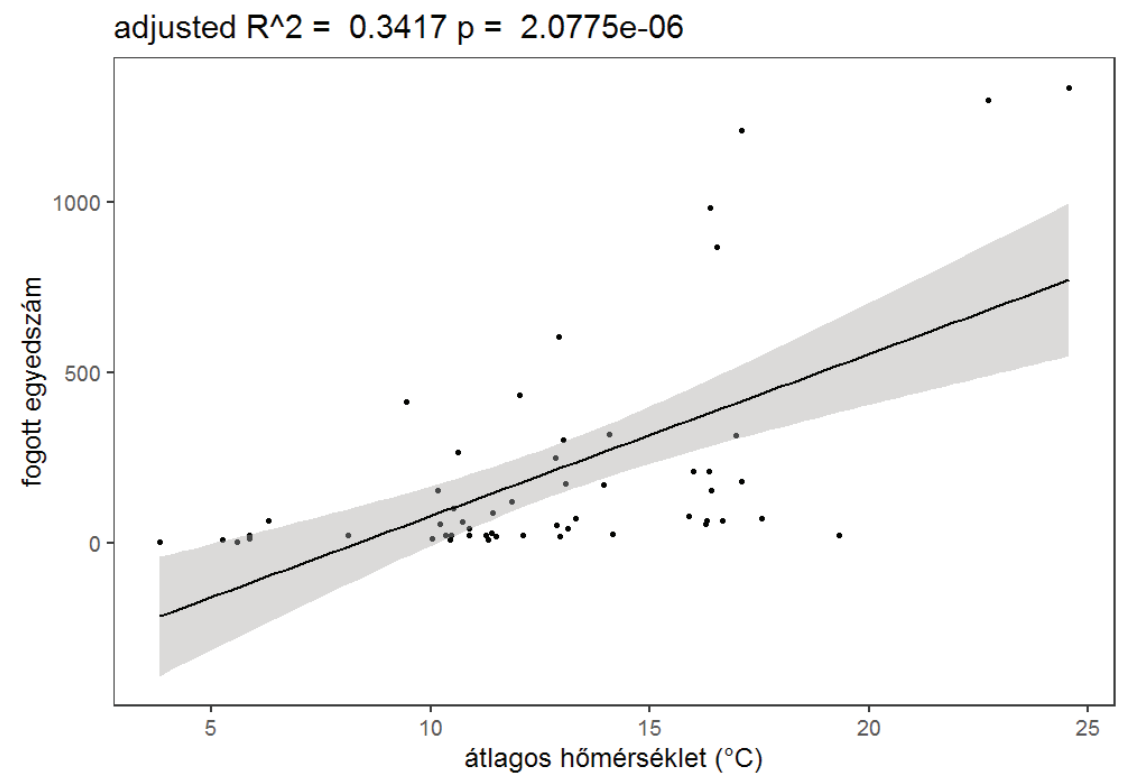

6. ábra. Fogott rovarok egyedszáma az átlagos hőmérséklet függvényében.

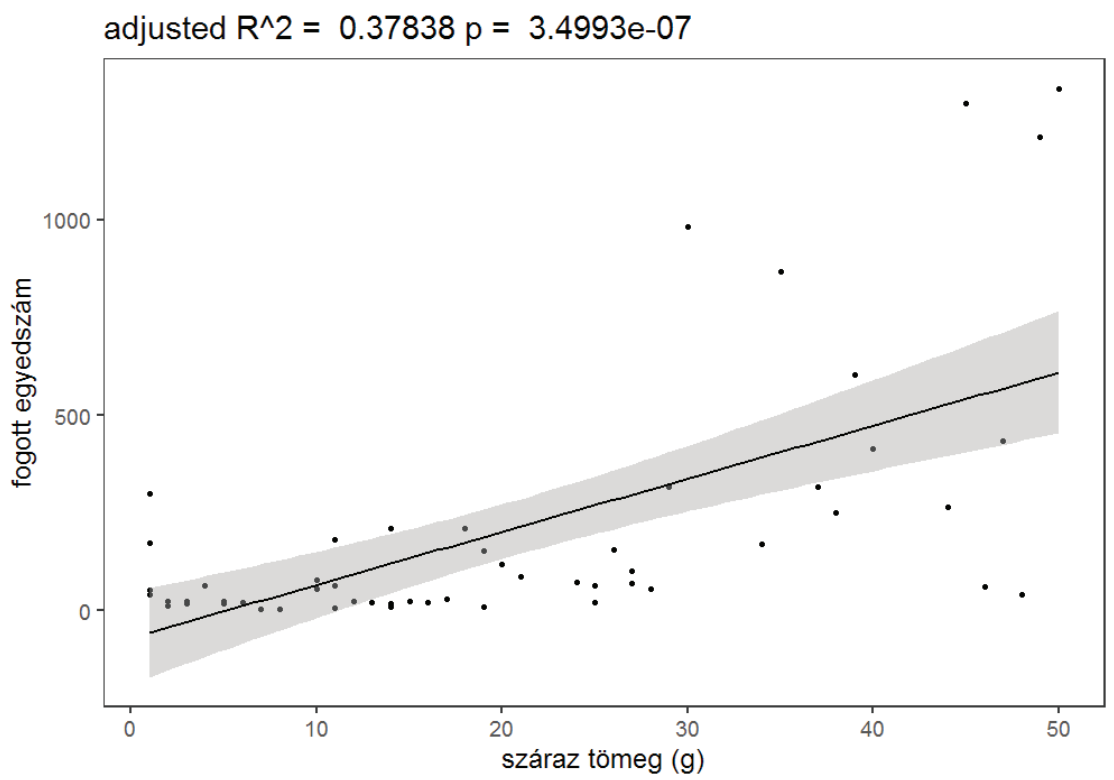

7. ábra. Fogott rovarok egyedszáma a száraztömeg függvényében. 
1. táblázat. Az eltérés iránya és mértéke a standard hibával (S.E.) a szignifikáns hatást gyakorló faktorok csoportjai között (Tukey HSD, $\mathrm{p}<0,05$ ). A szignifikáns elkülönülés félkövérrel jelölve.

\begin{tabular}{ccccccc}
\hline & \multicolumn{3}{c}{ Fogott egyedszám } & \multicolumn{3}{c}{ Száraztömeg $(\mathrm{g})$} \\
& eltérés & S.E. & $\mathrm{p}$ & eltérés & S.E. & $\mathrm{p}$ \\
\hline MVL - BL368 & 242,1 & 118,41 & 0,237 & 3,5 & 4,88 & 0,949 \\
CFL - BL368 & 81 & 128,15 & 0,969 & $-6,9$ & 5,2 & 0,652 \\
2700K LED - BL368 & -148 & 119,03 & 0,719 & $\mathbf{- 2 0}$ & $\mathbf{4 , 8 8}$ & $<\mathbf{0 , 0 0 1}$ \\
4000K LED - BL368 & $-104,2$ & 118,85 & 0,902 & $\mathbf{- 1 8 , 1}$ & $\mathbf{4 , 8 8}$ & $\mathbf{0 , 0 0 2}$ \\
CFL - MVL & $-161,1$ & 85,84 & 0,321 & $\mathbf{- 1 0 , 5}$ & $\mathbf{2 , 9 7}$ & $\mathbf{0 , 0 0 3}$ \\
2700K LED - MVL & $\mathbf{- 3 9 0 , 2}$ & $\mathbf{7 8 , 7 5}$ & $<\mathbf{0 , 0 0 1}$ & $\mathbf{- 2 3 , 6}$ & $\mathbf{2 , 7 3}$ & $<\mathbf{0 , 0 0 1}$ \\
4000K LED - MVL & $\mathbf{- 3 4 6 , 3}$ & $\mathbf{7 8 , 5 8}$ & $<\mathbf{0 , 0 0 1}$ & $\mathbf{- 2 1 , 7}$ & $\mathbf{2 , 7 3}$ & $<\mathbf{0 , 0 0 1}$ \\
2700K LED - CFL & -229 & 87,82 & 0,066 & $\mathbf{- 1 3 , 1}$ & $\mathbf{2 , 9 7}$ & $<\mathbf{0 , 0 0 1}$ \\
4000K LED - CFL & $-185,2$ & 87,67 & 0,208 & $\mathbf{- 1 1 , 2}$ & $\mathbf{2 , 9 7}$ & $\mathbf{0 , 0 0 1}$ \\
4000K LED - 2700K LED & 43,8 & 79,62 & 0,981 & 1,9 & 2,73 & 0,951 \\
\hline
\end{tabular}

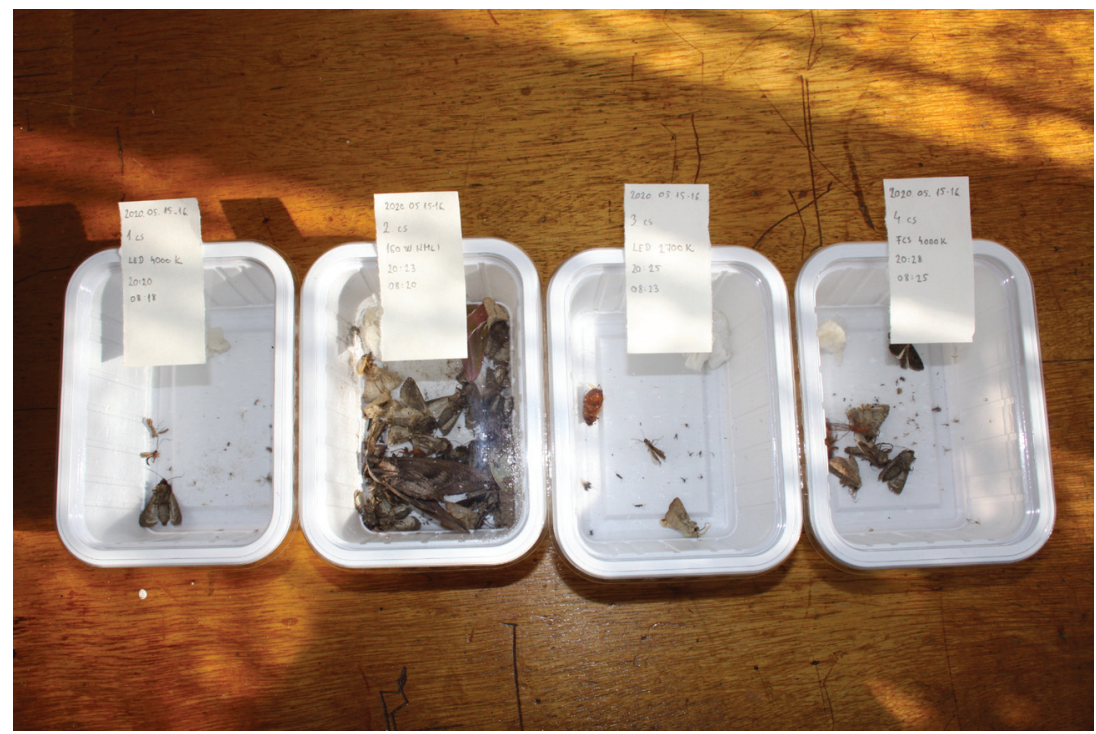

8. ábra. A csapdák által egy éjszaka alatt összegyüjtött minták, balról: LED $4000 \mathrm{~K}$, MVL 4000 K, LED $2700 \mathrm{~K}$, CFL $4000 \mathrm{~K}$.

\section{Megvitatás és konklúzió}

Kutatásunk elsődleges célja az eltérő színhőmérsékletü (spektrális összetételü) és fényintenzitású, közvilágításban is használt lámpák ökológiai hatásának elemzése volt. A folyamatosan müködő, automatizált szondák használata nagy mennyiségü, statisztikailag elemezhető adat összegyüjtését tette lehetővé. Így lehetőség volt az 
élőhelyükről eltávolított ízeltlábúak biomasszájának mennyiségi becslésére és a különböző színhőmérsékletű fényforrások vonzerejének elemzésére, ezáltal természetvédelmi kezelést megalapozó következtetések levonására.

Az eredmények alapján a hidegebb színhőmérséklet nagyobb attraktivitása mellett a fényintenzitás is igen jelentős tényező. A nagyobb fényerősségü lámpák több rovart fogtak el az azonos színhőmérsékletü, de kisebb fényerősségü lámpáknál. Kísérletünkben a legkevésbé vonzó lámpa a sárga LED (2700 K és 2450 lumen) volt. A 4000 Kelvines LED-es lámpa csak csekély mértékben volt nagyobb attraktivitású. Jelentős növekedés tapasztalható azonban a 4000 Kelvines 3040 lumenes kompakt fénycső esetében, és egyértelmủen a legvonzóbb a 4000 Kelvines színhőmérséklettel és 3100 lumen fényerősséggel rendelkező higanygőz lámpa.

A rovarok általában különösen érzékenyek a látható spektrum rövidebb hullámhosszú (kék) régióira és az UV fényre (Ashfaq et al. 2005). A rovarok fény felé orientálódásának hasonló mintázatát más tanulmányokban is publikálták (Thomas 1996). Az eredmények azt mutatják, hogy a rovarvonzó hatásért nagy részben a kék és az UV fény a felelős. Az éjszakai lepkék szeme a 380-400 nm-es hullámhossztartományra a legérzékenyebb, míg kevésbé érzékeny a hosszabb hullámhosszú spektrális régiókra (Menzel et al. 1986).

Kísérletünk megerősítette, hogy a színhőmérséklet fontos szerepet játszik a rovarok eltérő mértékü vonzásában. A meleg (sárgás) színhőmérsékletű, kevés rövid hullámhosszú komponenst tartalmazó fény kevésbé vonzó, mint a hideg (fehér és kék) fény. A fényintenzitás erőssége is fontos tényező. Az eredmények alátámasztják és megerősítik azt, hogy a természetközeli és védett természeti területeken és környékükön a kültéri világítás tervezésénél és megvalósításánál az élővilágra legkevésbé negatív hatást gyakorló, elsősorban meleg színhőmérsékletü (2200-2700 K), kevés kék spektrális komponenst tartalmazó és alacsony teljesítményü fényforrások alkalmazása kerüljön előtérbe.

Kiragadott aspektus, de ha naponta csak 1 grammnyi az a rovarmennyiség, amit egy közvilágítási lámpa befog (a méréseink szerint az egy éjszaka befogott rovarok nedvestömege a 36,6 grammot is elérte - 2020. 08. 09-ei mérés az MVL esetében), akkor a Magyarországon a közvilágításban használt mintegy 1300000 lámpatest tavasztól őszig, nagyjából 250 napot figyelembe véve, éves szinten mintegy 325 tonna rovart vont ki az élőhelyekről. Ezáltal jelentősen sérülnek az általuk nyújtott ökológiai funkciók és az ökoszisztéma-szolgáltatások (Lyytimaki 2013). Figyelembe véve, hogy egész Európában komolyan csökken a rovarok faj- és egyedszáma (Hallmann et al. 2017), minden kis lépés a közvilágítás természetbarátabbá tételére nagy jelentőséggel bír természeti értékeink megóvása szempontjából. 
Köszönetnyilvánitás - A kutatást az EFOP-3.6.2-16-2017-00014 projekt tette lehetővé. Köszönetet mondunk az Eszterházy Károly Egyetem, illetve a Bükki és Hortobágyi Nemzeti Park Igazgatóságok által nyújtott segítségért is.

\section{Irodalomjegyzék}

Ashfaq, M., Khan, R., Ashan, M., Rasheed, F. (2005): Insect orientation to various color lights in the agricultural biomes of Faisalabad. Pakistan Entomologist 27: 49-52.

Babbie, E. R. (1973): Survey Research Methods. Wadsworth Publishing, Belmont, 744 p.

Balla, E., Flórián, N., Gergócs, V., Gránicz, L., Tóth, F., Németh, T., Dombos, M. (2020): An optoelectronic sensor-ring to detect arthropods of significantlyd body sizes. Sensors 20: 982 . https:// doi.org/10.3390/s20040982

Bertholf, L. M. (1940): Reactions to light in insects. Bios 11: 39-43.

Benxuan, L., Mingxia, L., Jiangtao, F., Jingchao, Z., Smowton, P. M., Sohn, J. I., Il-Kyu, P., Haizheng, Z., Bo, H. (2020): Colloidal quantum dot hybrids: an emerging class of materials for ambient lighting. Journal of Materials Chemistry C 8: 10676-10695. https://doi.org/10.1039/ d0tc01349h

Cronin, T. W., Warrant, E. J., Greiner, B. (2006): Celestial polarization patterns during twilight. Applied Optics 45: 5582-5589. https://doi.org/10.1364/AO.45.005582

Davies, T. W., Bennie, J., Gaston, K. J. (2012): Street lighting changes the composition of invertebrate communities. Biology Letters 8: 764-767. https://doi.org/10.1098/rsbl.2012.0216

Dombos, M., Kosztolányi, A., Szlávecz, K., Gedeon, C., Flórián, N., Groó, Z., Dudás, P., Bánszegi, O. (2017): Edapholog monitoring system: automatic, real-time detection of soil microarthropods. Methods in Ecology and Evolution 8: 313-321. https://doi.org/10.1111/2041-210X.12662

Dombos, M., Flórián, N., Gergócs, V., Schellenberger, V., Haszon, B., Nagy, A. (2018): Ízeltlábúak automatikus detektálási problémái és megoldásai terepi vizsgálatokban. In: Szép, T. (szerk.): 11. Magyar Ökológus Kongresszus: Absztraktkötet. Magyar Ökológusok Tudományos Egyesülete, Nyíregyháza, p. 30.

Ferreirade, D., Souzaa, P., Fernandesda, P., Silvaa, L., Almeida, F., Fontenelea, G., Damaceno, B., Marcelode, O. J. (2019): Efficiency, quality, and environmental impacts: A comparative study of residential artificial lighting. Energy Reports 5: 409-424. https://doi.org/10.1016/j. egyr.2019.03.009

Hallmann, C. A., Sorg, M., Jongejans, E., Siepel, H., Hofland, N. Schwan, H., Stenmans, W., Müller, A., Sumser, H., Hörren, T., Goulson, D., de Kroon, H. (2017): More than 75 percent decline over 27 years in total flying insect biomass in protected areas. PLoS One 12: e0185809. https://doi. org/10.1371/journal.pone.0185809

Huemer, P., Kühtreiber, H., Tarmann, G. (2010): Anlockwirkung moderner Leuchtmittel auf nachtaktive Insekten - Ergebnisse einer Feldstudie in Tirol (Österreich). Wissenschaftliches Jahrbuch der Tiroler Landesmuseen 4: 110-135.

Ködöböcz, V. (2018): Fényen gyüjtött futóbogarak (Coleoptera: Carabidae) a debreceni Malompark Bevásárlóközpontnál, 2000 és 2018 között. Folia Historico-Naturalia Musei Matrensis 42: $71-82$.

Lyytimäki, L. (2013): Nature's nocturnal services: Light pollution as a non-recognised challenge for ecosystem services - research and management. Ecosystem Services 3: e44-e48. https://doi. org/10.1016/j.ecoser.2012.12.001 
Menzel, R., Ventura, D., Hertel, H. (1986): Spectral sensitivity of photoreceptors in insect compound eyes: comparison of species and methods. Journal of Comparative Physiology A 158: 165-177.

R Development Core Team (2020): R: A Language and Environment for Statistical Computing. R Foundation for Statistical Computing, Bécs. https://www.r-project.org/

Rich, C., Longcore, T. (2006): Ecological Consequences of Artifical Night Lighting. Island Press, Washington, $458 \mathrm{p}$.

Thomas, A. W. (1996): Light trap catches within and above the canopy of a northeastern forest. Journal of Lepidopterist's Society 50: 21-45.

Internetes források:

http1: https://helion.hu/zoolog

\title{
How common light sources differ in attracting insects: A case study using long-term data via ,Zoolog” monitoring system
}

\author{
István Gyarmathy ${ }^{1 *}$, Tamás Korompai ${ }^{2}$, Béla Mester $^{1} \&$ \\ Richárd Novák ${ }^{2}$ \\ ${ }^{1}$ Hortobágy National Park Directorate, H-4024 Debrecen, Sumen u. 2, Hungary \\ ${ }^{2}$ Bükk National Park Directorate, H-3304 Eger, Sánc u. 6, Hungary \\ "E-mail: gyarmathyistvan@hnp.hu
}

Our primary goal was to analyze the ecological impact of lamps with different color temperatures, also used as street lights. Quantitative data on arthropods attracted by light traps were recorded by an automatic sampler (Zoolog), along with temperature and humidity data. Long term monitoring of the amount of arthropod biomass removed from its habitat by the different types of light sources has been made possible by the statistical analysis of the acquired large dataset, thus analyzing the attractiveness of lamps with different color temperatures as well as changes in daily and long-term activity. The above study is complemented by the measurement of the dry mass of the captured biomass, as well as the planned species-level determination of the macrolepidoptera fauna occasionally trapped in the traditional way. Our results make it possible to draw conclusions that help nature conservation management and the regulation of public lighting in protected areas.

Keywords: light pollution, remote sensing, color temperature, light trap, conservation management 